Research Report No. 27/2009

\title{
Transnationalizing Mexican Legal Education: But, What About Students' Expectations?
}

Luis Perez Hurtado

Follow this and additional works at: http://digitalcommons.osgoode.yorku.ca/clpe

\section{Recommended Citation}

Hurtado, Luis Perez, "Transnationalizing Mexican Legal Education: But, What About Students' Expectations?" (2009). Comparative Research in Law \& Political Economy. Research Paper No. 27/2009.

http://digitalcommons.osgoode.yorku.ca/clpe/140 


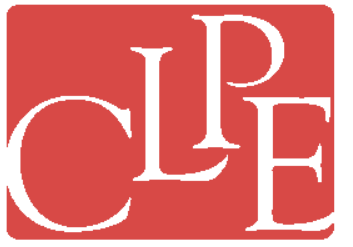

\section{Comparative Research in Law \& Political Economy}

\section{Luis Perez Hurtado}

\section{Transnationalizing Mexican Legal Education: But, What about} Students' Expectations?

EDITORS: Peer Zumbansen (Osgoode Hall Law School, Toronto, Director, Comparative Research in Law and Political Economy, York University), John W. Cioffi (University of California at Riverside), Nassim Nasser (Osgoode Hall Law School, Toronto, Production Editor)

Also available at: http://www.germanlawjournal.com 



\title{
German Law Journal
}

\begin{abstract}
Transnationalizing Mexican Legal Education: But, What about Students' Expectations? Luis Perez Hurtado
\end{abstract}

10 German Law Journal 767 (2009), available at:

http://www.germanlawjournal.com/article.php?id=1119

This article was originally published in Volume 10, Number 7 of the German Law Journal as part of the journal's $10^{\text {th }}$ anniversary symposium on "Transnationalizing Legal Education" edited by Nadia Chiesa, Adam de Luca, and Bernadette Maheandiran. 
CLPE Research Paper 27/2009

Vol. 05 No. 04(2009)

\title{
Luis Perez Hurtado
}

\section{Transnationalizing Mexican Legal Education: But, What about STUDENTS' EXPECTATIONS?}

\begin{abstract}
This article focuses on exploring the diversity of ways future students are exposed to law, as well as the multiple reasons that make the profession and degree attractive for them. It is based on the question "what experience or specific situation led to your interest in studying law?" that we asked almost 22,000 Mexican law students around the country at the beginning of the 2004-2005 academic year.

This analysis is important because current efforts to transform legal education tend to consider only international components to incorporate into the law programs. But these reforms should also consider the regional or local needs of the participants of legal education which until now have not been taken into account. For example, as we describe in this article, one of five Mexican law students chose to study law because they or their relatives had been victims of violations to their rights, or as a result of perceiving their environment as marked by injustice, corruption and impunity. Law for them was a way to do something about it or, at least, be able to protect themselves and their families. This is a reality shared not only by other Latin American countries, but probably by most developing countries. Any reform to legal education should explore ways to incorporate the students' ideas, interests and experiences into their studies not only to improve the program, but also to stimulate the students and increase their motivation.
\end{abstract}

Keywords: Legal education, Curricular changes, Mexican Legal Education

JEL classification: K10, K40

Luis Perez Hurtado

Director of CEEAD - Centro de Estudios sobre la Enseñanza y el Aprendizaje del Derecho (Research Center on Legal Education) based in Monterrey, Mexico (www.ceead.org.mx).

LL.B. Universidad Panamericana Mexico City, LL.M. Harvard Law School, J.S.M. and J.S.D. Stanford Law School. Email: luisph@ceead.org.mx 


\title{
SPECIAL ISSUE: TRANSNATIONALIZING LEGAL EDUCATION
}

\section{Transnationalizing Mexican Legal Education: But, What About Students' Expectations?*}

\author{
By Luis Fernando Perez Hurtado**
}

\section{A. Introduction}

The number of Mexican institutions of higher education (hereinafter also referred to as "Institutions" or "IHE") offering Bachelor's Degrees in Law has increased rapidly. For example, in the 1997-1998 academic year, there were 364 Institutions offering the basic law degree; by the 2006-2007 academic year, the number had increased to $930 .{ }^{1}$ It is as if, over the last ten years, each week a new IHE began offering a Bachelor's Degree in Law. During that same period, law school enrollment in Mexico increased from 170,210 to approximately 240,000 . By 2003, the Bachelor's Degree in Law was the degree program with the highest enrollment in the country - 11 out of 100 students at the college level chose it. ${ }^{2}$

Some of the principal causes of this growth include: 1) the increased availability of higher education in Mexico, in general, as a response to the growing demand for higher education programs; 2 ) the ease with which a new law program could be started, including the low investment required; and 3 ) the diverse reasons that students have to study law. ${ }^{3}$

Following the last point, this article focuses on exploring the diversity of ways future students are exposed to law, as well as the multiple reasons that make the profession and degree attractive for them. It is based on the question "what experience or specific

\footnotetext{
* This article is based on Chapter IV of Luis Fernando Pérez Hurtado, The Next Generation of Mexican lawyers: A Study OF MEXICo's SYSTEM OF LEGAL EdUCATION AND ITS LAW StUdenTS (2008) (unpublished J.S.D. dissertation, Stanford Law School) (on file wih the Stanford University Library).

** Director of CEEAD - Centro de Estudios sobre la Enseñanza y el Aprendizaje del Derecho (Research Center on Legal Education) based in Monterrey, Mexico (www.ceead.org.mx). LL.B. Universidad Panamericana Mexico City, LL.M. Harvard Law School, J.S.M. and J.S.D. Stanford Law School: luisph@ceead.org.mx

${ }^{1}$ Sources: 1997-98, author's estimation based on data from Dirección de Análisis y Sistemas de Información, SEP; 2006-07, data collected by the author, available at: www.educacionjuridica.org. Last accessed: 26 March 2009.

${ }^{2}$ ANUIES, Anuario Estadístico 2003, Licenciatura en Universidades e Institutos Tecnológicos, Resúmenes y Series Históricas 17 (2003), available at: http://www.anuies.mx. Last accessed: 26 March 2009.

${ }^{3}$ See Luis Fernando Perez Hurtado, An Overview of Mexico's System of Legal Education, MexicAn LAw RevieW (forthcoming March 2009).
} 
situation led to your interest in studying law?" that we asked almost 22,000 Mexican law students around the country at the beginning of the 2004-2005 academic year.

This analysis is important because current efforts to transform legal education tend to consider only international components to incorporate into the law programs. But these reforms should also consider the regional or local needs of the participants of legal education which until now have not been taken into account. For example, as we will describe in this article, one of five Mexican law students chose to study law because they or their relatives had been victims of violations to their rights, or as a result of perceiving their environment as marked by injustice, corruption and impunity. Law for them was a way to do something about it or, at least, be able to protect themselves and their families. This is a reality shared not only by other Latin American countries, but probably by most developing countries. Any reform to legal education should explore ways to incorporate the students' ideas, interests and experiences into their studies not only to improve the program, but also to stimulate the students and increase their motivation.

Before describing the methodology of our study and for those not familiar with legal education in Mexico, it is important to mention some general characteristics in order to understand the context we are analyzing:

a) The formal academic program that allows graduates to practice as lawyers - Licenciatura en Derecho or LED - is not a graduate program, as it is in the United States, but an undergraduate degree preceded by a high school degree.

b) At the beginning of the 2006-2007 academic year, there were 930 institutions offering the LED. In general, those institutions function only as centers for the transmission of knowledge. Less than $20 \%$ of the IHE that offer the LED are involved in research or in academic extension activities. Some Institutions offer two or more LED in the same facilities that are different in modality (i.e. full-time, part-time, open- or distance-learning), duration and/or approach.

c) In most of the IHE, the curriculum is rigid. This means that students at each level are assigned their courses, their professors, and their schedule without the possibility of making choices regarding these matters. In every law program, students take between 40 and 70 mandatory courses during their studies.

d) Over $90 \%$ of the law professors combine teaching with professional practice, and most of the law programs do not have full-time faculty.

e) The cost for opening and operating a law program is low. In general, all that is required is a few lecturers paid a low salary, facilities set up for educational purposes with one classroom for each level, and a library with the books that are recommended for each course. 


\section{B. Methodology}

This article comes from a broader study on Mexican legal education that aimed to analyze its main elements: the institutions of higher education and their regulatory framework, faculty, students, study plans and programs, and the context for the teaching-learning process. For that study, we developed and implemented a multi-component field research plan; this included observations, interviews, document analysis, as well as the use of questionnaires. ${ }^{4}$

\section{Units of Analysis}

For the analysis of law students, subject of this article, we applied a questionnaire to students enrolled in full-time Licenciatura en Derecho. It means students in programs that required full-time attendance, but no part-time, open- or distance-learning programs. ${ }^{5}$ The questionnaire was short, with most questions open-ended, to be answered anonymously. The open-ended question format was used to allow students to express themselves freely. ${ }^{6}$

\section{Sample Design and Size}

We developed a list of 691 schools that were offering the full-time LED at the end of the 2003-2004 academic year, which formed the base for our sampling. To make inferences about the different kinds of institutions and compare them, we divided the IHE into three Groups or strata: Public, Private 1 and Private 2.

Institutions Considered for the Sampling: ${ }^{7}$

\footnotetext{
${ }^{4}$ See luis Fernando Pérez hurtado, The next Generation of Mexican lawyers: A Study of Mexico's System of Legal EDUCATION AND ITS LAW StUdENTS (2008) (unpublished J.S.D. dissertation, Stanford Law School, on file wih the Stanford University Library).

${ }^{5}$ Students in full-time programs represent over $90 \%$ of the LED enrollment.

${ }^{6}$ The observation dimensions and main variables follow: general characteristics (gender, age, program level, month and year of entrance to the LED, type of high school, socioeconomic status, scholarships, high school and LED grades, languages, and place of residence); choosing to study the Licenciatura en Derecho (other options before considering the LED, experiences that motivated the interest in a law degree, purpose and expectations for studying for the LED); choosing the IHE (other options before considering the current institution, selection of the specific IHE, advantages and disadvantages of legal education in current IHE); and practice of law (studentwork experience, professional interests, perception of factors for getting a job, factors of professional success, and plans for further studies).

${ }^{7}$ Estimation based on data from Dirección de Análisis y Sistemas de Información, SEP.
} 


\begin{tabular}{|l|l|l|}
\hline & Institutions & Enrollment \\
\hline Public & 89 & 104,693 \\
\hline Private 1 & 290 & 60,536 \\
\hline Private 2 & 312 & 42,782 \\
\hline LED & 691 & 208,011 \\
\hline
\end{tabular}

We included in the Public Group all public institutions, that is, those founded by the federal or state governments, and financed mainly with public resources.

In the Private 1 and Private 2 Groups, we included all private IHE, that is, those founded by individuals or private entities, and mostly financed with tuition and student fees. There are substantial differences among private institutions, mainly derived from their different goals, academic experience and prestige, and their access to economic and human resources. Therefore, we divided the private institutions into two groups. In the Private 1 Group are those private IHE that were classified as "of good quality" using the following criteria. The IHE in Private 1 is:

a) A member of one of the following associations of higher education that require minimal quality standards, such as the ANUIES, the Federation of Private Institutions of Higher Education (Federación de Instituciones Mexicanas Particulares de Educación Superior, hereinafter referred to as "FIMPES"), or the Southern Association of Colleges and Schools (hereinafter referred to as "SACS"); ${ }^{8}$ or

b) One of the best universities at the regional or national level according to the Reader's Digest 2004 University Guide; ${ }^{9}$ or

c) Member of a group or system of institutions where at least one of its IHE is a member of ANUIES, FIMPES or SACS, or that has been considered one of the best universities at the regional or national level according to the Reader's Digest 2004 University Guide. The purpose here is to include institutions that benefit from being part of a specific group of IHE that may allow them to have access to economic and human resources for their development.

d) Additionally, we have included the Escuela Libre de Derecho de la Ciudad de Veracruz, Escuela Libre de Derecho de Sinaloa, Facultad de Derecho de la Barra Nacional de Abogados, Facultad Libre de Derecho de Monterrey, and Facultad de Derecho de Tlaxcala

\footnotetext{
${ }^{8}$ See ANUIES (www.anuies.mx), FIMPES (www.fimpes.org.mx), and SACS (www.sacs.org). Institutional members of these associations have followed a certification program that shows somehow their commitment to quality.

${ }^{9}$ GUÍA UNIVERSITARIA READER's DIGEST, EDICIÓN ESPECIAL, AÑo 2, NúMERO 2 (2004).
} 
for the following reason: they have some prestige in their community, and since they offer only law programs, they are less interested in becoming members of the associations mentioned before, and it is more difficult for them to be recognized among the best IHE at the regional or national level, due to their size and specialization.

In the Private 2 Group are all the private IHE not included in the Private 1 Group. Many of these institutions have been criticized for providing low quality education. However, we do not know much about these institutions and most of them have a non-traditional approach to education and/or they are on their way to consolidation. ${ }^{10}$

We placed each IHE in one of the three groups, we used a stratified cluster sampling for the specific case of students. Each group was considered a stratum (Public, Private 1, or Private 2) and 15 institutions were randomly selected from each group. ${ }^{11}$ Each institution was a cluster and we included the totality of students within each cluster. ${ }^{12}$ The number of IHE included in the study was determined by taking into consideration the sample needed to reach the study's objective and the time and budget available for visits to schools.

\footnotetext{
${ }^{10}$ It is necessary to clarify two aspects regarding the Groups. First, we used these "quality" criteria because they allow us to divide the private Institutions into two groups with different characteristics. Not enough information about IHE was available to apply other grouping criteria. Furthermore, there were no generally accepted criteria for defining the quality of private Institutions, such as formal accreditation. The formal accreditation of Licenciaturas en Derecho began only in 2006. These circumstances led us to use the criteria described above.

Second, there are differences among IHE in the Public Group, due mainly to the perception that these Institutions differ in their prestige and in the academic experiences they provide to students. Nevertheless, most of public IHE belong to a university system, which means that they have access to economic and human resources for their development, and they benefit from that access. For instance, associations such as ANUIES consider the whole university system, not the IHE alone, for acceptance. Then, if the same criteria for dividing private IHE were applied to public IHE, most of them would be in a "Public 1" group. Few IHE would be in a "Public 2" group, and they would have less than $5 \%$ of the law students enrolled in public Institutions. For this reason, we placed them in a single group.

${ }^{11}$ The random selection included the following modifications: (1) In the Public Group, we included UNAM Ciudad Universitaria because of the impact it has on many IHE at the national level. (2) A new sample was taken whenever two or more IHE from the same system of IHE were drawn, to avoid having Institutions with very similar characteristics and with access to the same economic and human resources.

${ }^{12}$ This sampling method offers four advantages: (1) The strata division increases precision and allows us to have a substantial number of students in each stratum. (2) The cluster division assures a more efficient use of economic resources. (3) The inclusion of the totality of students in each cluster allows us to have a substantial number of students with different characteristics, and hence, the possibility to compare them. (4) The observation of all the elements in their context allows for the analysis of students, not isolated, but interacting with factors within their Institutions that may influence their decisions.
} 


\section{Data Collection}

The visits to institutions took place between July and October 2004. Our goal was to conduct visits during the two first months of the 2004-2005 academic year ${ }^{13}$ primarily to obtain the perspectives of new students before they became fully immersed in their studies. $^{14}$

The student questionnaires were administered in the classrooms during a class period. All classes in session during the day that we were at an institution were visited so we could distribute questionnaires to all the students attending classes that day. ${ }^{15}$ From the 36,319 students enrolled in the 45 Institutions, 21,789 were present that day and responded to the questionnaire, yielding an overall response rate of $60 \%$. We personally administered $85 \%$ of the questionnaires; the rest were administered by the IHE and then sent to us. ${ }^{16}$

\section{Data Analysis}

We coded all the data and used the SPSS and STATA programs to analyze the answers on the student questionnaires, and used two weights to analyze the data. The first weight assigned to each questionnaire a value proportional to the total number of students in each Institution. The purpose of this weighting procedure was to correct for differences in rates of completion of questionnaires at the various institutions. It takes into account the academic level of each student, and it is used when making inferences about each Group or stratum. The second weight assigned to each questionnaire a value representative of the total population in the full-time Licenciatura en Derecho. The purpose of this second weighting procedure is to correct for differences in the proportion of questionnaires that had been completed in each stratum, while taking into account the first weight. It is used when making inferences about all law students in full-time programs.

\footnotetext{
${ }^{13}$ Most of the new law students start classes during those months. From 63,271 first-year law students during the 2004-2005 academic year, 55,108 (87\%) stated their studies during that term. Source: Dirección de Información de la SEP.

${ }^{14}$ Due to logistic and time problems, the visit and questionnaire application were performed at the end of the 2003-2004 academic year in four IHE.

${ }^{15}$ We do not have any reason to think that the students that were absent the day of the questionnaire application may have different profiles from those that completed the questionnaire.

${ }^{16}$ We were not able to personally apply the questionnaires in some institutions because some groups did not have class that day or the director decided not to interrupt classes that day. We did not collect from two institutions, both from the Private 2 Group. One of them, with approximately 40 students, did not return any completed questionnaires. The other institution did not have any students that semester; this is rather common in Group Private 2, so we decided to analyze the case instead of repeating the random selection of the Institutions.
} 
To be able to find differences among students, the questionnaire also collected general information, such as gender, age, socioeconomic status (SES) and LED grades.

\section{Constraints and Considerations}

As with any research, there are constraints and considerations that limit how much these findings can be generalized. First, very little is known about legal education in Mexico, especially regarding the law students. Our intention is to provide a catalyst for new research on the matter by showing the existence of diversity in IHEs offering the LED. In addition, we want to point out problems common to all IHEs, as well as problems that require further study.

Second, as we mentioned before, a large part of this work is based on the answers the students gave in their responses to an open-ended questionnaire. Aside from the difficulties in coding and classifying the 21,798 completed student questionnaires, our main goal was to open a space where students could express themselves, so we could learn about previously unexplored aspects of their backgrounds. There is no doubt that many aspects of law students' experiences remain to be analyzed, and that different conceptual and operational frameworks will be required to further explore such information.

Third, there is a risk that students may have given answers different from their true feelings and perceptions, because their responses may reflect what they thought they were expected to say. We tried to reduce this risk by insisting during the process of administering the questionnaires that students' responses be submitted anonymously. We also tried to reduce this risk by personally administering and collecting most of the questionnaires, rather than having that done by someone affiliated with their institution. Moreover, using open-ended questions as opposed to a multiple-choice format helped reduce that risk.

Fourth, we tried to identify students by Group of IHE, not by institution. This was done with the goal of focusing our attention on the phenomenon that we were observing instead of on the institution that was producing it.

Finally, the questionnaires and the responses were in Spanish. Therefore, every quotation from a person cited in this study is a translation by the author from Spanish to English.

\section{Interests in the Licenciatura en Derecho}

We asked the students, "What experience or specific situation led to your interest in studying law?" Students' responses were varied and rich in information, and they allowed us to explore (1) the factors that brought students into contact with law as a field of study; 
(2) what they liked about law after they had made contact with it as a field; and (3) the perspectives regarding law that they brought with them when they entered the LED. ${ }^{17}$ Collecting and analyzing data on these issues allowed us not only to better understand students' interests, but also to explain the high demand for law studies.

Student responses can be divided into six "General Topics" or categories: (1) a specific experience: $48.3 \%$; (2) knowledge of what is being studied: $18.9 \%$; (3) knowledge of the extent to which someone in that field can provide assistance: $17.4 \%$; 4 ) knowledge regarding professional practice: $14.4 \%$; (5) general liking of the field: $14.2 \%$; and (6) other: $8.5 \%$. The total of these percentages is greater than $100 \%$ because the responses of some students included more than one factor - that is, their responses addressed more than one category. ${ }^{18}$

Moreover, we will note if there are significant differences in numbers of responses falling into particular categories as a function of Group, Gender, Age, SES or LED grades. One of our objectives in identifying these differences is to encourage further research to elucidate the causes of these differences. In every instance where the text states that a "significant difference" was found, we are referring to a statistically significant difference at the 0.05 level:

\section{Specific Experience (48.3\%):}

The category of Specific Experience refers to the concrete situation that places students in contact with law and its institutions. This includes a situation involving injustice, influence of family members or acquaintances, contact at a professional level, and contact at an academic level.

a) Situation involving injustice: One of the main experiences that raise the interest of students for the law program is that they were victims of violations to their rights, or they perceived their environment as marked by injustice, corruption and impunity.

\footnotetext{
${ }^{17}$ The answers to this open-ended question were very difficult to code and classify, because they diverged greatly from a simple "I liked it", to more elaborate answers such as: "Simply because I like to act with confidence and this program allows me to avoid many injustices by knowing the law and how I can avoid arbitrary actions of society and authorities. Besides I was a victim of an injustice in a car accident", "Because some social situations that are in great crisis and because moral values are destroyed, young people with criteria and preparation to face them are needed, as well as with a great sense of rightness. I like the legal environment and diplomacy," or "More than anything was helping people, and since I had knowledge of the program it caught my attention. The lawyer as a mediator, as judge, etc. is what I like the most. I think lawyers are a very good model although they have lost their professionalism and ethics."

${ }^{18}$ The responses of $79.7 \%$ of students fell into only one general category, while $18.4 \%$ fell into two general topics and $1.9 \%$ three general topics. $1.8 \%$ of the students did not answer this question.
} 
Approximately one of every five students (17.5\% of the student total) expressed it this way.

There were many specific examples involving violations of rights. Those affected included: The students themselves: ("I was left unprotected after my father died," "Unfavorable situations in relation to law application by power organs such as accusations; slander towards me when I was only twelve years old").

The students' family or friends: ("One day I saw that the husband of my neighbor was hitting her and the police didn't do anything. I was 10 years old, she went to report her husband and a few weeks or months later he was free and that is not fair," "An uncle unfairly in jail," "I had the unfortunate experience of seeing my father assassinated and there was no justice against his killers").

Other people in the students' community: ("The fact that in the place where I live they abuse children, there is intra-family violence and wanting to help children and women is what raised my interest in law," "Seeing an indigenous person being unjustly accused for the simple fact he didn't speak Spanish," "The arrogance of public safety officials, especially policemen because they are capable of beating and robbing a person if they are alone at night," "The discrimination against indigenous people of the North Mountains in Papantla, Veracruz").

More general situations: such as the indigenous uprising in Chiapas, the assassination of Luis Donaldo Colosio, problems involving the North American Free Trade Agreement, electoral frauds and university strikes.

Those who spoke of unfavorable environment, mainly refer to injustices ("The great injustices existing in Mexico relating to less privileged social classes, with low resources"), corruption ("Because I'm tired of corrupt people"), rights violation ("the constant citizen rights violations by the public authorities), and impunity ("The impunity of almost $80 \%$ of the cases in Mexico"). In some cases a specific group of people affected by these situations is mentioned, mainly the poor, women, children, indigenous and the uneducated. Also some state that they know about these issues because they, their family or friends, or their community are the ones affected and in other cases they know about these issues through television, newspapers, magazines or discussion groups.

A large number of students mentioned lawyers as one of the causes of the problems they perceived ("The lack of honest lawyers or politicians in Mexico," "Because I was an spectator of truly embarrassing situations where lawyers sell themselves and violate their ethics, and this is what motivated me to change this type of situation") or of violations suffered ("The injustices against a family member when he gave his case to a corrupt lawyer," "I had too many bad job-related problems with lawyers who accepted money and I 
lost the cases, ending without a job and money, in 3 cases," "A lawyer swindled my parents"). ${ }^{19}$

The responses also illustrate what the students expect to do and the impact they wish to have with their law studies. In relation to situations of injustice, students consider that they can repair the damage ("Because they unjustly took my father's ranch away and he was left with nothing. The same person who sold him the ranch took it away. I plan to recover it one day through the legal route," "Watching my family with legal problems and not having the money to pay"), their law studies will provide them knowledge of how to avoid these situations ("For the injustices and violations Mexican society experiences because of ignorance and lack of knowledge of the institutions to which they can go to exercise their rights," "The abuses of authority caused by the lack of legal knowledge by the general population"), well-prepared, honest lawyers are needed ("I consider that there are many poorly prepared lawyers and so, well prepared lawyers are needed," "Because although there are too many lawyers not all of them have the necessary capability"), and as a lawyer they can help to change ("Seeing that impunity is everywhere and being able to contribute to make this stop," "Because I am really worried about the political and legal situation of the country, and I believe that Mexico deserves that all of us worry and improve the current situation in the country").

Significant differences exist when we consider Group, Gender and SES. The percentage of students who mentioned a situation involving injustice as the factor that led to their interest in law is greater in students at Private 2 and Public Institutions, in women and in students with middle-low or low SES.

b) Influence of family members or acquaintances: $16.6 \%$ of students responded that the profession, advice or example of their family and/or acquaintances led to their interest in law. Most students in this group answered that what aroused their interest is that their father, mother, siblings or other family members are lawyers or work in legal institutions. However, the way this impacted their decision varies, because it could be by: tradition ("There are many lawyers in my family"), more contact with law ("I worked for a while in a family firm," "By reading law books, because there are many lawyers in my family," "Watching my uncles litigate"), better knowledge of law ("My family and friends are lawyers so they explained what they did and I liked it") or job guarantee ("Because my personal situation inclined me to study law, because I sincerely consider that I had a door opened (by my father) and I would have to struggle less when finding a job"). In relation to job guarantee, it is worth mentioning that it not only applies to those whose family

\footnotetext{
${ }^{19}$ Not all opinions about lawyers are negative. In other categories good comments are made about them and some examples are given ("Once I saw how a lawyer helped a family free of charge and this motivated me to do something for my fellow man").
} 
members are lawyers, but to all of those whose family members work in places where a lawyer is needed, both in the public and private sector.

Another group responded that their interest arose from interaction with acquaintances who are lawyers or law students. The types of interaction included conversations (" $A$ lawyer I know told me about his bachelor's in law with such enthusiasm that I decided I wanted the same"), or by observing what they did ("One friend I talked to was studying for that degree and I started going with him to court, notaries, etc., and that raised my interest in law").

Some students answered that they decided to study law because of a family-member suggestion, even if they were not lawyers ("I have always liked commerce, but my father suggested law because it is a more complete program than commerce and besides I can practice law"). A much smaller group stated that their family-members imposed it or that it was convenient for their family ("Because in my family there are no lawyers," "Because my family needed a lawyer, which was very expensive and because my dad wanted me to be a lawyer and because I like it"). In general, we observe significant differences by Group, age and SES. The percentage of students who stated the influence of family-members or acquaintances as the reason for their interest in law increases in Private 1, in students of 19 years old or less or in those with a middle-high or high socioeconomic status.

c) Contact at a professional level: $8.9 \%$ of the student total answered that the situation that raised their interest was contact with the practice of law - by visiting a law related place, ${ }^{20}$ watching a lawyer practice the profession, ${ }^{21}$ working in a place related to law, ${ }^{22}$ relating professionally with lawyers, ${ }^{23}$ or for a legal problem. ${ }^{24}$ Even though most students simply said that their interest came from a contact with law or its institutions in general, the more detailed answers showed that the percentage of students who had a negative experience and decided to prepare themselves was higher than the percentage of those who had a positive experience that led them to study law.

\footnotetext{
20 "Visiting civil and criminal courts."

21 "When an uncle was fired and I accompanied him to the labor courts with his lawyer."

22 "I worked as a secretary in a legal firm and I liked it," "I was interested in the LED because I work in the courts."

23 "I worked for 2 years in a company where I worked with lawyers and that created my admiration for them."

24 "In relation to a lawsuit made against a company I worked for, my benefits were not paid completely so I sued them and I won; I liked it a lot because I was in all the labor courts, and people many times don't have the money to pay a lawyer or someone that represents them."
} 
Significant differences by Group, age and SES were found. The percentage of students who stated the contact at a professional level was the reason why they got interested in law rises in Private 2 and in Public, in students older than 24 years of age or middle-low or low socioeconomic status.

d) Contact at an academic level: $5.6 \%$ of the student total stated that contact with law during their studies in high school or even before was what raised their interest in studying law. ${ }^{25}$ Among the ways they were exposed to law were conferences, contests, talks, internships, visits, research and pro bono service. Some also mentioned professional counseling in high school, such as aptitude, vocational and psychometric exams, talks with professional counselors and psychologist, and college fairs. However, the most mentioned influence was a specific course ${ }^{26}$ or a teacher. ${ }^{27}$ The specific courses mentioned not only refer strictly to legal courses, but also courses in politics, international relations and even oratory, which students associate with law programs. A significantly greater percentage of women students than men students mentioned a previous academic contact as the situation that led to their interest in law.

e) Other: A very small percentage of students mentioned a different specific experience. These stated that reading a book or article - generally the Constitution-, learning more about a historical character, listening to a conference talk by a successful lawyer, contact with successful people or watching a movie (mainly "The Devil's Advocate" and "A Few Good Men") or an American TV show made them want to know more about law.

The specific issues we just analyzed illustrate to us the things that link students with law and its institutions. The following categories study what is what they like about law once they are in contact with it.

\section{Knowledge of what is being studied (18.9\%):}

This category refers to the interest of students in the content of law studies, especially in knowing the laws and their rights and obligations. As reasons for being interested in this knowledge, some students mentioned its importance, ${ }^{28}$ specific legal areas, ${ }^{29}$ related

\footnotetext{
${ }^{25}$ In this group we also included some students who took law courses while they studied for a different bachelor's degree and that is why they transferred, or attended law classes as an occasional student before deciding which academic program to study and law caught their attention ("I attended a tax law class and I loved law, the code, and the discussion was very good").

26 "The law class we had in high school," "I liked social sciences and humanities in high school," "The way they taught me in high school how justice was delivered."

27 "Influence of a high school teacher who was a lawyer, his way of teaching and his work as a lawyer."

28 "I consider that the bachelor in law should be studied by most if not all people, because of its relevance."
} 
areas $^{30}$ or general knowledge. ${ }^{31}$ Contrary to "popular belief", the percentage of students who expressed that they were interested in law because it had no math or other disciplines was very small. ${ }^{32}$

There were significant differences in this area between Groups. The percentage of students who stated that knowing what is being studied raised their interest for studying law is greater for those in Private 2.

\section{Knowledge of the extent to which someone in that field can provide assistance (17.4\%):}

This refers to the help that law can give to the students, their families and/or society. Students referring to help for themselves or their families think about law as a self-defense tool. The answers about helping society have different focuses: General ("[I]nterest in being a person who helps society"); on general problems ("I would like to help to create a country that was more just to all, avoid corruption and injustices, and I think that being a lawyer brings me closer to being able to contribute in something"); on specific sectors ("Wanting to do justice in order to end inequalities with regard to indigenous and poor people", "Because some day I would like to defend people who are in jail for no reason"); on being a good lawyers ("Serving society and trying to eliminate the bad reputation of lawyers (a thief with a degree)").

A significant percentage of students said they were attracted by the possibility of helping themselves and their family through their studies, as well as by the possibility of helping others. $^{33}$

There were no significant differences with regard to this topic by Group, gender, age, socioeconomic status and LED grades.

\footnotetext{
29 "Because I am attracted to everything related to criminal law," "I am a public accountant and I like everything related to tax and labor law."

30 "I like law very much, besides it is not all about law issues but also social, economic, cultural and political issues; it is a very complete program."

31 "The high cultural level we get compared to other degrees."

32 “I don't like math or English, I also don't like computer skills, arts and management, etc."

33 "The need to know in order to defend myself and others; it can give a sense of safety and altruism at the same time."
} 


\section{Knowledge regarding professional practice (14.4\%):}

Here we group students who were interested in the different aspects of the professional practice of a lawyer - diversity in areas of practice, access to a specific professional field, wide range of jobs, characteristics of the professional practice, and the lawyer's role in society.

a) Diversity in areas of practice: These students are attracted to the variety of areas where they can work. ${ }^{34}$ In addition, some add their interest in combining or complementing it with other degrees. ${ }^{35}$

b) Access to a specific professional field: Most mention politics, litigation and criminology. $^{36}$

c) Wide range of jobs: the many job opportunities perceived by students. ${ }^{37}$

d) Characteristics of the professional practice: This mainly refers to the activities of a lawyer, $^{38}$ the professional environment ${ }^{39}$ and remuneration. ${ }^{40}$

e) Lawyer's role in society: Includes the perception students have about the importance of lawyers. $^{41}$

The significant differences seen in this category are by Group, gender and SES. The percentage of students who reported that having knowledge about the professional

\footnotetext{
34 "I think that by being a lawyer I have my options open to enter almost any work field."

35 "I am a public accountant and I wish to combine both degrees", "Ideal complement for my first degree and I really like this program."

36 "I want to be a public servant or work in politics, and I believe that this is an excellent degree to have access into politics", "By studying law, I can then become a criminologist."

37 "I wanted a broad job offer", "What made me interested in law was that I realized that no one is exempt from having legal problems and needing legal counsel, because problems are present even in your own family". We noted that a high percentage of these students tend to infer that the diversity of study branches is synonymous with a diversity of job opportunities.

38 "I always found the job of a lawyer interesting and in a certain way exciting."

39 "I like the environment where a lawyer works."

40 "Because they say that a good lawyer makes good money."

${ }^{41}$ "I think that a lawyer is a person people respect and a base point of society", "The importance it has in society, the leadership they show managing others."
} 
practice raised their interest for studying law is relatively greater if they are part of Private 1 , if they are men or if they are of middle-high or high SES.

\section{General liking of the field (14.2\%):}

Most students in this category answered that the factor leading to their interest was simply their liking for the degree. ${ }^{42}$ However, some stated that they have the abilities required in the profession, such as being able to work in a team, facility in the use of written and spoken language, people skills and taste for reading and debates; or that they have the values needed in the profession. ${ }^{43}$

\section{Other (8.5\%):}

Some responses were too infrequent to be assigned a separate category classification; such responses were placed in the category of "Other". Following are examples of those responses:

- Study development ("The fact that it is a very theory inclined program, I like to read and memorize, it is easier than practical programs," "I like to read a lot and it is a degree where you need to read")

- Getting into a specific institution ("The interest of being part of an institution like this one");

- Difficulty ("I wanted a difficult degree, very formal and where I had to read a lot");

- Ease ("Because I have a very low IQ for other programs," "Because it is a degree not so complicated and gives me the opportunity to keep working," "I didn't study other programs because I know myself, I wouldn't make it in other programs"); associated Opportunities ("There are more opportunities to study law than other programs," "Law awakens the creativity and ability in the mind," "Because it is the cheapest one," "To have a profession and enter the police academy");

- Perceived lack of other options ("It was something I would study while I found another program, but I liked it and I stayed," "Because I had no choice; because my high school education was not good in math, I felt I was no good in that course and today I realize I am good but it is too late," "Because there was no other program where I was," "Because it was the least saturated and I passed the exam").

\footnotetext{
42 "It was something spontaneous," "Since I was young, I wanted to study law," "It simply caught my attention."

${ }^{43}$ We can also infer from the answers that these characteristics are discovered by the students themselves, other people mention them ("I asked the people I know what they thought I would be good at and $90 \%$ said as a lawyer, I thought about it, did my research and fell in love with my program," "Thanks to my friends, because I argued too much and said that I wouldn't be a bad lawyer because I had character"), or they discover it in professional counseling.
} 


\section{Conclusion}

Some of the main reasons for the high demand to study law come both from the diversity of ways future students are exposed to law, as well as the multiple reasons that make the profession and degree attractive. On the one hand, students were exposed to law mainly through day-to-day experiences, especially those involving violations of rights or because they perceive an environment marked by injustice, corruption and impunity (almost one in every five students), the influence of family members or acquaintances, contacts at a professional level with the practice of law or through a contact during previous school levels, a class, a paper, a teacher or an academic conference. On the other hand, once students have had contact with law, this field can be attractive because of the content of the study plan; the protection training in law can give them, their family or society; or the characteristics of the professional practice, the job of a lawyer and associated personal benefits such as income, prestige and contacts. Each one of the ways the students are exposed to the legal field, and of the reasons they consider the legal field attractive affect students' perceptions of what law as a field of study is, and especially what can be achieved with it.

The ongoing debate regarding the quality and relevance of legal education in Mexico should explore ways to incorporate the students' ideas, interests and experiences into the study plans, not only to improve the program, but also to stimulate the students and increase their motivation. If we add that the main students' criticism to their programs is the lack of a practical component, one that takes into account the context in which law develops and its application to specific cases, the topic is essential to improve the relevance of law school programs. 